\title{
ИГРОВОЙ МОМЕНТ В ИССЛЕДОВАНИИ ПРЕДСТАВЛЕНИЙ О ДУШЕ И ДУХАХ У СЕЛЬКУПОВ
}

\author{
Марта Ивановна Федорова \\ кандидат культурологии \\ Муниципальное учреждение культуры \\ «Красноселькупский районный краеведческий музей»
}

Следуя установкам философской герменевтики, которая рассматривает культуру как языковую реальность и делает акцент на необходимость её понимания, для селькупской традиционной духовной культуры обратимся к феноменам души (ильсат) и духа (лос).

Известно, что в мировоззрении селькупов представление о душе самое конкретное, о чём ярко свидетельствует следующий рассказ о том, что есть душа. «Однажды летом Светлана с матерью или по лесной тропе к реке проверить сети. И вдруг дочь увидела: впереди по тропе идёт молодая женщина, очень на неё похожая, как будто двойник. Светлана удивилась, позвала и даже побежала за ней. Так называемый двойник тут же ускорила шаг и побежала, после стала уходить в сторону и, не скрываясь из виду, исчезла. Светлана спросила мать: “Ты видела?”. Она ответила: “Да”. Дочь спросила мать, что такое, что за явление. Мать сказала, что это её ильсат (душа). Мать также отметила, что это плохая примета, которая говорит о том, что Светлана может заблудиться в лесу. Но, чтобы примета не сбылась, Светлана должна отдать кому-либо пальто, которое было в тот момент на ней. Дочь по какой-то причине не выполнила наказ матери. Так и случилось, осенью девушка заблудилась, хотя была недалеко от чума. Как могло такое случиться? Ведь она знала здесь каждый уголок? И вспомнила тогда Светлана про тот случай с двойником и предостережение матери. Она не стала больше испьтывать судьбу: пальто тут же было распорото и использовано для шитья кӱты пәмы - голенищза бакарей» [1].

Мать и дочь в данном рассказе - представители традиционного образа жизни селькупского народа. Дочь пытается следовать традиционным правилам, но культурный смысл обретается лишь в разговоре, то есть при осуществлении взаимопонимания. Взаимопонимание - процесс, в котором проживается жизнь человеческого сообщества. Благодаря взаимопониманию она становится действительностью. Понимание является игрой. Тот, кто 
понимает, всегда втянут в то свершение, в котором заявляет о себе осмысленное. Герменевтические концепции уделяли внимание проблеме рецепции, тогда как процедура кодирования информации оставалась за пределами их внимания. Далее мы переходим от герменевтических к логикосемантическим концепциям, которые уделяли основное внимание репрезентации предмета мысли, отражающей явление действительности и образующей понятийные аспект речевой деятельности, способности речи передавать информацию, независимо от способности человека формулировать или воспринимать эту информацию.

Исходя из приведённого примера, для раскодирования содержания предмета нашего исследования - души «ильсат», овладев научными материалами (этнографическими в первую очередь), переходим к расшифровке наименования её изображения - поркя (изобразить одежду: селькупское поркы - одежда, кятыка - изобразить). Ильсат (душа) есть поркя. Образ (ильсат как душа) неотделим от общего смысла текста, он является связующим элементом, «посредником» между содержанием текста и его языковым выражением. Он обеспечивает необходимую концептуальную связь между языковым выражением и содержанием текста.

Поркя - антропоморфная деревянная фигура в виде куклы - кумия («двойник» человека; буквально: «человечек»), вместилище для души. Семантический анализ «поркя» показывает, что данный термин полифункционален. Селькупское слово поркя - общее название любого изображения, сделанного селькупом с какой-то конкретной целью или по указанию шамана. Практическое применение поркя разнообразно. Выделим некоторые формы поркя и критерии полифункциональности данного сакрального предмета.

Поркя делают после рождения (когда появляются зубы) и поселяют в семейном или в родовом культовом амбарчике под защитой духов природы. После смерти человека это изображение становится духом предков и продолжает храниться в амбарчике теперь уже в качестве духа кусалос (поселькупски: дух, который должен умереть), через некоторое время его сжигают. Селькупы, как привило, не ходят на кладбище, так как полагают, что душа человека через некоторое время покидает тело через дырочку на крышке гроба. Селькупы боялись покойников и во время следующих похорон соблюдали на кладбище все меры предосторожности, что предполагало определённый обряд. С духами умерших предков они могли общаться в 
глухой тайге, в священных амбарчиках, где хранились изображения родовых предков и где имелось одно общее мольбище.

Поркя - это также и личина (антропоморфное изображение), вырезанная на стволе растущего дерева, находящегося в обиталище какого-либо духа мачыл лос. Селькуп, незаметно для себя перешедший неведомую границу, идёт к священному месту и приносит подарок духам иного мира (кормит их), просит прощения.

Поркя трактуется и как изображение духов в их функции помощников шамана, когда присутствует на подвесках шаманского костюма. Это антропоморфные уродцы, они могут быть без головы и с хвостами. Либо зооморфные изображения - птицы (лебеди, гагары), пресмыкающиеся (ящерицы). Они помогают шаману в путешествии соответственно в верхний (птицы, олень) или нижний (ящерицы, медведь) мир.

Следовательно, поркя есть изображение души и духа. Призрак живого человека в традиционной духовной культуре селькупов обозначается термином ильсат (душа), а призрак умершего термином кусалос (селькупское кука - умереть, лос - дух). Значит, термин лос соотносится с сущностями иного мира (или параллельного мира) - духами предков. Поэтому субъективное отношение к духу обозначается, словом лос. Другой существенный момент в традиционном селькупском мировоззрение заключается в том, что при земной жизни человека духи-лос есть только у шаманов.

Чтобы объяснить этот существенный момент в мировоззрении селькупов, обратимся к исследованиям С. Грофа, в частности, к книге «Холотропное сознание: Тексты трансперсональной психологии» [2, с. 96], чтобы вновь оказаться в игровом отношении к мифологическому мировоззрению и лингвистическим трактовкам. Трансперсональное существует независимо от нас. К. Юнг, наблюдавший это в своих ранних встречах с духом-проводником Филемоном, утверждал, что все мысли принадлежали не ему самому, а его проводнику. Юнг обращался со своими мыслями, как с порождёнными им самим. Для Филемона «мысли были подобны животным в лесу, людям в комнате или птицам в воздухе». Юнг пришёл к выводу, что Филемон преподал ему «психическую объективность, реальность психики». Он писал: «Во мне существует нечто такое, что может изрекать то, чего я не знаю и чего не подразумеваю» [3, с. 249-290]. 
Мы уже знаем, что душу-ильсат, покидающую своё физическое тело, селькупы воспринимают как сущность саму по себе: например, её можно обмануть. В иррациональной интерпретации ильсат (душа) есть «одежда». Подтверждение этому (помимо речевой практики уральских и тюркских языков), мы находим у М. Элиаде, который рассказывал, как эскимосский шаман сказал своему ученику: «Ты умрёшь. Но ты вновь обретёшь своё тело, ты пробудишься, и твоя одежда прилетит к тебе» [4, с, 65]. В момент мистической смерти шамана (кумпа), и когда шаман пробуждается (в потустороннем мире), и когда душа-ильсат (одежда) возвращается к нему, он «чувствует» юнговского Филемона. Таким образом, душа-ильсат в потустороннем мире (то номқын - в другом мире) есть его мысли (одеждадвойник - сознание), которые представляются как дух-лос. Камлающий (селькупское қ̧амытырка) шаман говорит на языке духов-лос (язык шамана селькупам непонятен). Шаман трансцендирует, выходит за пределы чувственного опыта, за пределы эмпирического познания мира.

Анализируя данные эмпирической психотерапии, С. Гроф обнаруживает, что во время психоделических сеансов трансперсональный опыт не только отражает материальный мир, но тесно переплетается с другими видами опыта, например, юнговскими архетипами - образами демонов, божеств, полубогов, супергероев и комплексом мифологических, легендарных и сказочных эпизодов [5, с. 63]. Точно также на арену традиционного селькупского мировоззрения выходят следующие архетипы: Илынтый Кота (Жизненный Мешок), Тйй Имыл (Огонь Бабушка), Мәркый пальчай Имыля (Ветра Бабушка), Ү̈тый Имыля (Бабушка Вода), собственно лос (Дух), мачьл лос - Кор-Нум (дух местности - Дух Медведя), Кандальдук (Корневой Старик), кусалос - Лос има кота (дух, Старуха Дух) и другие.

Важная особенность традиционного селькупского представления о духовной сущности человека и её посмертном существовании выявляется на основе лексического анализа следующей фразы: «Сейкум қэтыыты эnа. Мунтың чем қумпот қэтылынын қ̧алымпа» («У каждого селькупа дух был. Хоть они все и умерли, но дух их остался»). Здесь в субъективном отношение к духу от термина лос мы переходим к термину қэты - «мудрость», «чудо», «необычность». Этнографические исследования показали, что появление термина қэты связано с появлением посукый рашай кампыя (полоска ткани на ветвях деревьев, полоска ткани на надгробном памятнике, полоски ткани на шесте шамана, полоски ткани на одежде шамана). 
Бессмертие человеческой души в традиционной духовной культуре селькупов выражено в персонифицированных мифологических образах, таких как поркя, посукый рашай кампья, которые являются способом связи между профанным и сакральным мирами. Поркя, посукый рамай кампыя символическое выражение сакральной сущности (в настоящее время предстают в виде ритуальных предметов и атрибутики шаманского костюма). Их глубинный, основополагающий сакральный смысл выявляется в результате этимологического анализа словообразования. Анализ понятий проясняет специфику селькупского национального сознания. Функционально поркя и посукый рашай кампыя являются предметами культа. Теоретикопознавательное же своеобразие идеи бессмертия души связано с самопостижением человека, с погружением в глубины внутреннего мира, в собственное Я.

Подтверждением этому является тот факт, что граница иного мира в западносибирской традиции не имеет пространственной локализации, это характерно и для селькупов. В мировоззренческих представлениях селькупов присутствует идея о взаимосвязи всех миров. Связь осуществлялась через определённые точки в пространстве: в чуме - у очага через огонь, в месте напротив входа (сыткий); в тайге - в священных местах через деревья (посукый рашай кампыя), культовый амбарчик (поры); у истока реки, у устья в городе покойников (латарый қэты), на кладбище (латарый мәкты). В этих точках непосвящённые селькупы вступали в общение с потусторонним миром, осуществляли связь с ним через изоморфных духов огня - Тӱй Имия (Бабушка Огонь), ветра - Мәркый пальчый Имия (Бабушка Вихрь); через различных персонифицированных духов предков (мачы лосы, кусалос, посукый рашай кампыя).

Традиционная селькупская духовная культура через индивидуальное сознание выводит нас на современную картину мира. В акте рождения чельципа (селькупское - появление из света) мы прослеживаем трансцендентное движение «энергетического паттерна» - духа-луча (лучезарного) из сакрального мира в профанный в качестве души-ильсат. Трансформирующая сущность человекообразного духа-луча в акте рождения человека, снизошедшего в душу-ильсат, в профаном мире выступает уже как персонифицированная сущность Дух Огня - Туй Имия («Огонь-бабушка»). Ү̈тый Имия («Бабушка Вода») есть образ околоплодных вод, из которых 
рождается человек, и образ Великой Матери, животворного начала Вселенной, по-селькупски Ильнтый Кота («Жизненный Мешок»).

Понимание текста предстаёт как экзистенциальное и вместе с тем игровое событие человеческой жизни, а осмысление прошлой культуры выступает как форма самоосмысления индивида и общества. Онтологическое условие понимания - его укоренённость в традиции, «причастность» её бытию как субъекта, так и объекта понимания, способствующая трансляции опыта от поколения к поколению и тем самым обеспечивающая континуум традиции. Интерпретация текста, таким образом, состоит не в воссоздании первичного (авторского) смысла текста, а в создании смысла заново. Каждый акт интерпретации - событие в жизни текста, момент его «действенной истории», а тем самым и звено «свершения традиции», но вместе с тем и игровой факт. Интерпретация культурной традиции рассматривается как диалог прошлого и настоящего. Фундаментальной характеристикой человеческого бытия и мышления является историчность: его определённость местом и временем и, следовательно, той «ситуацией», в которой человек себя застаёт - определёнными «правилами игры» в интерпретацию. Наши исследования показали, что в «мистическом опыте трансцендентные причины становятся имманентными» $[6,608$ с]. Игра в данном случае и есть перевод трансцендентного в имманентное.

\section{Список литературы}

1. Личный архив автора (информант: С.А. Каргачёва, 1969 года рождения, село Толька, Красноселькупский район Тюменской области, запись 2006 года).

2. Гроф С. Холотропное сознание: Тексты трансперсональной психологии. М., 1996. С. 96.

3. Юнг К. Об архетипах коллективного бессознательного // Юнг $K$. Божественный ребёнок. М., 1997. С. 249-290.

4. Элиаде М. Шаманизм. Архаические техники экстаза. Киев; М.; СПб., 2000. C. 65.

5. Там же. С. 63.

6. Алексеев П. В., Панин А. В. Философия. М., 2003. 608 с. 